\title{
嗅上皮の特性と鼻腔内投与による中枢神経機能のマニュピレーション
}

\author{
柏 柳 誠
}

\section{Characteristics of Olfactory Epithelium and Manipulations of Neural Functions in the Brain by the Intranasal Administration}

\author{
Makoto Kashiwayanagi \\ Department of Sensory Physiology, Asahikawa Medical University; \\ Higashi 2-1, Midorigaoka, Asahikawa, Hokkaido 078-8510, Japan.
}

(Received July 30, 2012)

\begin{abstract}
Olfactory cells receive numerous odorants including toxic substances. To avoid complete loss of the olfactory function by toxic odorants, continuous neurogenesis of olfactory cells occurs even at adulthood. Newly generated olfactory neurons extend their axons to the olfactory bulb. Various molecules including polypeptides, proteins, polynucleotides, virus, and cells administrated intranasally have been reported to move from the olfactory epithelium to the brain tissue via the olfactory epithelium-olfactory bulb pathway. I discuss the pathway of substances intranasally administrated to the brain from the view point of characteristics of the olfactory epithelium.
\end{abstract}

Key words_ _ intranasal; neural function; olfactory epithelium; olfactory bulb

\section{1. はじめに}

脳血管関門は，脳に存在する脆弱な性質を有する 神経細胞を危険な化学物質から防御している。しか し, 脳血管関門が存在するが故に, 水溶性の高い薬 物あるいは分子量が大きい薬物は特殊なキャリアー がない限り，脳内に移行することはできない，脳血 管関門を介さずに脳に薬物を送る方法は，いくつか 考えられている．例えば，脳室内に薬物を直接注入 することも有効である．しかし，この投与方法は患 者に痛みを生じさせるとともに危険を伴う。また, 脂溶性を高めたり, 細胞が本来持っているキャリ アータンパク質を介しての輸送が可能となるように 薬物の分子構造を変えることも有効である. ${ }^{1)}$ 本総 説が紹介するのは，脳血管関門をバイパスするため に嗅上皮から嗅球にいたる嗅覚経路を中枢神経作用 薬の輸送経路として利用するストラテジーである.

\section{2. 嗅上皮の特性}

嗅細胞は, 多種多様に存在する匂い物質を受容す

The author declares no conflict of interest.

旭川医科大学生理学講座神経機能分野（下078-8510 旭

川市緑が丘東 2 条 1 丁目)

e-mail: yanagi@asahikawa-med.ac.jp

本総説は, 日本薬学会第 132 年会シンポジウムS29 で

発表したものを中心に記述したものである.
る能力を獲得した神経細胞である，神経細胞なの で，嗅細胞は軸索を有している (Fig. 1)。さらに, 匂い物質を受容したときに生ずる受容器電位を活動 電位に変換する能力も有している，嗅細胞が受容す る匂い物質の種類は, 10 万種類とも 40 万種類とも 推定されている．酸素や窒素などのごく一部の物質 を除いて，揮発する性質を有する物質は，嗅細胞で 匂いと認識される，揮発する性質を持つた物質の中 には，細胞にとって有毒な性質を有するものも多く 存在する.したがって, 嗅細胞は常に有害な匂い物 質により傷害を受けるという危険に直面している. ヒトでは嗅覚の喪失が生死に係わることを日常生活 で実感することは稀である。しかし，ヒト以外の生 物では，嗅覚系の喪失により，慨を探すことができ ない，あるいは，自分が慨として捕食されてしまう というように生死に係わる危険と直面することにな る.そこで，嗅覚機能を完全に喪失しないように獲 得した仕組みは，損傷の有無は問わずに新しい嗅細 胞に定期的に置き換える方法である. ラットでは, 30 日で㖵細胞はその寿命を終え, 基底細胞から分 化した新しい嗅細胞がその機能を受け継いでい

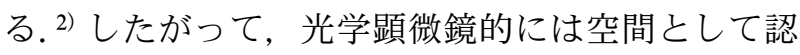
めることはできないが, 嗅細胞が存在している嗅上 


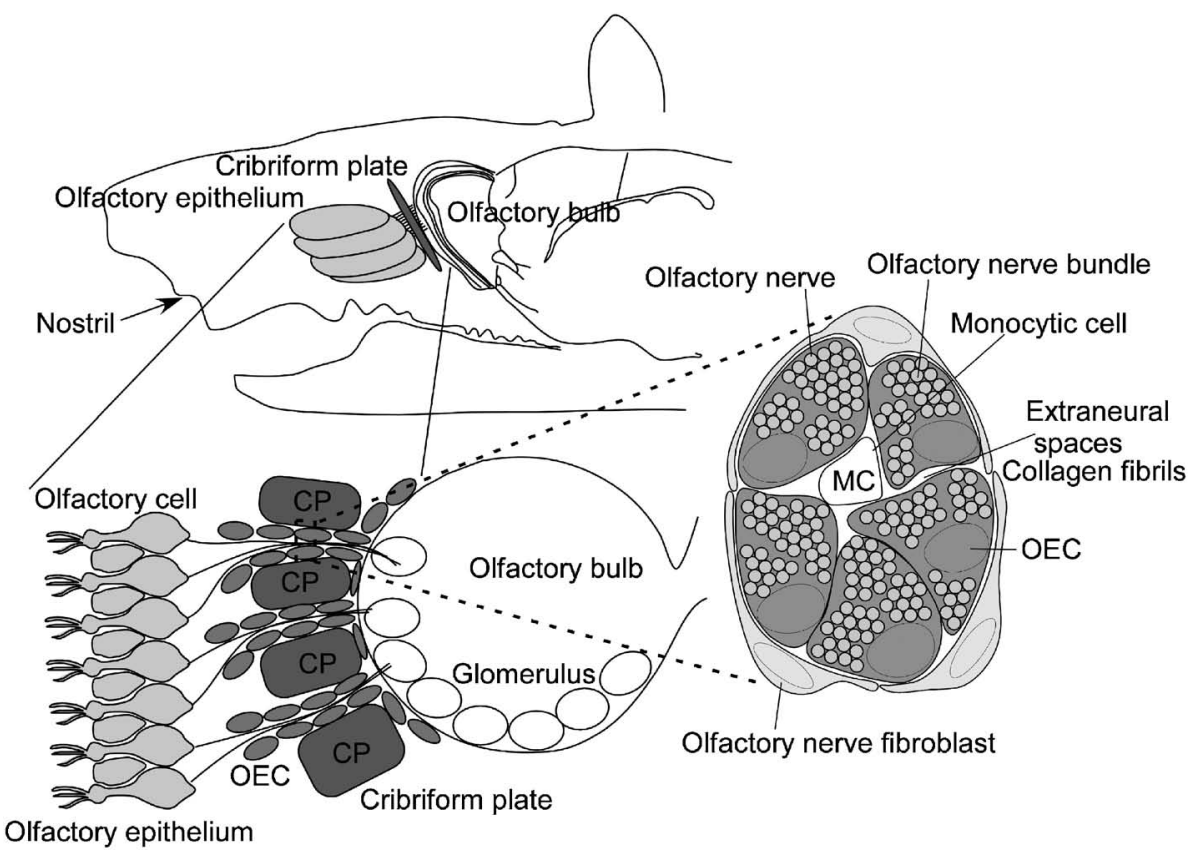

Fig. 1. Structure of the Olfactory Epithelium and Olfactory Nerve Bundles

Axons from the olfactory cells enter nerve bundles, which innervate to the olfactory bulb via cribriform plate. Olfactory ensheathing cells (OECs) are enclosed by a basal lamina separating them from a collagen filled extracellular space, and they ensheathe axons. Olfactory nerve fibroblasts surround multiple bundles of OECs and olfactory axons. Monocytic cells and collagen fibrils exist between the basal lamina-bound units in the extraneural spaces within the olfactory nerve fascicle.

皮は，常に脱落する細胞が作り出す隙間が豊富に存 在していることが想像される。すなわち，わずか $100 \mu \mathrm{m}$ ほどの厚みを有する嗅上皮は，常に細胞の 脱落と置換が繰り返されている脆弱な構造を有して いると言える。その状況は，嗅神経の軸索束でも同 様である，嗅上皮に存在する嗅細胞からのびている 嗅神経束は，篩板と名付けられた骨を隔てて接して いる嗅覚一時中枢の嗅球に入力する．篩板は，嗅神 経束が透過するための穴をいくつも有している。し たがって，嗅上皮と嗅覚一次中枢である嗅球は，空 間的に非常に近く位置している。このことも，嗅上 皮一嗅球経路が脳血管関門をバイパスする経路とし て機能することが期待できる長所の 1 つである．嗅 細胞が脱落すればそれに付随する嗅神経も消失す る。そその跡を，新生した嗅細胞から伸展する軸索が 埋めている。したがって，嗅神経束は嗅上皮と同様 に，隙間が他の神経束と比べて比較的多く存在する ことが想像される.

嗅神経の一本一本は有髄神経として髄鞘で覆われ ているのではなく，嗅神経束として嗅覚系に特異的 に存在するグリア細胞（olfactory ensheathing cell; OEC）で覆われている，神経束を内在するいくつ かの OEC は基底膜で覆われている，基底膜で覆わ
れた神経束-OEC の束と束の間には，コラーゲン線 維を含んでいる隙間が存在している. ${ }^{3}$ 基底膜で覆 われた神経束は，さらに繊維芽細胞で覆われてい る。また，基底膜で覆われた神経束を内在している OEC の間には，嗅上皮からのウイルス感染を防御 する働きがあると考えられる単核球が存在してい る. ${ }^{4)} \mathrm{OEC}$ は，新生した嗅神経が神経軸索の伸展を 助ける働きをしている可能性が考えられている。 こ のため，損傷した春髄の神経軸索の伸展を促す効果 が期待され，脊損部位への OEC の移植も試みられ ている. ${ }^{5)}$ 嗅球に投射する神経軸索は，嗅細胞が新 生すると嗅上皮から新たに伸展することを繰り返し ていることから，OEC は神経束を十分に密着して 覆つていない可能性も考えられる。このようなこと から，鼻腔内に投与された物質は，嗅上皮の間隙を 通過して, 嗅神経軸索の間隙あるいは神経束と

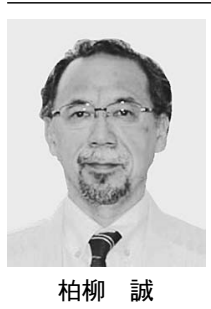

1984 年北海道大学大学院薬学研究科修 了 (薬学博士). 2003 年旭川医科大学 生理学第二講座教授. 2006 年旭川医科 大学生理学講座神経機能分野教授. 2004-2009 年日本味と匂学会誌編集委 員長. 1986 年第 2 回井上研究奨励賞. 1987 年第 3 回中西奨励賞. 1997 年秋山 財団賞（協同研究者）. 
OEC の間隙を満たしている脳脊髄液に到達する可 能性が考えられる。このような嗅神経系にのみみら れる特殊な性質が，脳血管関門を介さない脳神経系 の治療を行う薬物伝送経路として考えることを可能 としている.

\section{3. 鼻腔内投与によい脳内に移行する分子}

ヒトを含む動物で嗅上皮一嗅球を介した薬物伝送 経路により，様々な物質が脳内に運ばれる可能性が 示されている．例えば，ラットの鼻腔内に ${ }^{3} \mathrm{H}$ でラ ベルしたドーパミンを投与すると，30 分後に脳脊 髄液，外側嗅索，左右の嗅球，小脳及び大脳皮質の すべてで，静脈内注射による投与よりも高い放射活

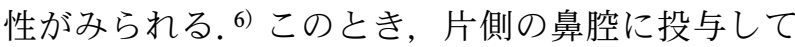
も，嗅球の左右に大きな違いは認められない。ささら に，ラットの鼻腔内に投与されたドーパミンは，10 分で新線条体と側坐核のドーパミン濃度を上昇させ る.7)腹腔内投与で同程度のドーパミン濃度を上昇 させるためには，10 倍の濃度で投与する必要があ る. また，ドーパミンの鼻腔内投与されたラットで は，グルーミングが減少するとともに，運動活動が 上昇する，マウスの鼻腔でも ${ }^{3} \mathrm{H}$ でラベルしたドー パミンを投与すると， 30 分で投与側の嗅球で放射 活性が認められ，4 時間まで持続するが 8 時間経つ と放射活性がみられなくなる. ${ }^{8)}$ 鎮痛薬のメプタジ ノールを鼻腔内投与すると 30 分後に脳脊髄液中の 濃度が増加する. ${ }^{9)}$ また， 3 種類のグリシン受容体拮 抗薬（GW468816, GV196771, GV150526）とアン ジオテンシン拮抗薬 (GR138950) をラットの鼻腔に 投与すると素早く脳に移行する. ${ }^{10)}$ GR138950 は 1 分で嗅脳における濃度が上昇するとともに，静脈内 投与よりも高い濃度で存在する. ${ }^{14} \mathrm{C}$ でラベルした GR138950 は，オートラジオグラフで観察すると， 篩板には存在せず，嗅神経束に存在する.

鼻粘膜には，三叉神経の自由終末が存在してい る.リドカインをラット鼻孔に投与すると 30 分以 内には，嗅球に高濃度に存在する。これは，嗅上皮 一嗅球経路を経由した結果を示す。一方，間脳，中 脳，小脳や脳幹にも，嗅球と間脳の間に存在する脳 の領域よりも高濃度でリドカインが存在する. ${ }^{11)}$ ま た，投与した薬物とは接することがない上顎大臼歯 や上顎切歯を支配する三叉神経にも高濃度で存在す ることから，鼻腔に投与された薬物が脳内に移行す る経路には，嗅上皮一嗅球経路だけではなく，三叉
神経を経由する可能性も示されている.

ラットやマウスでは，タンパク質や核酸だけでな くウイルスも脳に移行することが報告されている. 例えば，ボラノウイルスは，ラットの鼻腔内に感染 させると 6 日後に嗅球で初めて検出され，その後, 脳の全領域でみられるようになる. ${ }^{12)}$ 低分子やポリ ペプチドと比べて嗅球まで移行するまでに時間がか かるのは，嗅神経の軸索内を経由して，脳に移行す るためと考えられる. ${ }^{13)}$ また，マウス肝炎ウイルス を鼻腔に感染させても肝炎ウイルスの脳への移行が

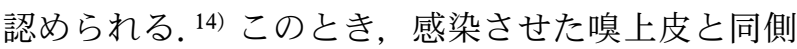
の嗅球を除去すると脳内に移行しない。このため, マウス肝炎ウイルスも，嗅上皮一嗅球経路を経由し て脳内に感染し，脳炎や脱䯣を引き起こすと考えら れている，驚いたことに，蛍光標識したヒトグリ オーマやラット間葉性幹細胞をマウスの鼻腔に投与 すると，嗅球，海馬や視床に標識された細胞が認め

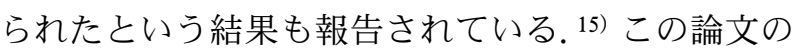
著者らは, 篩板を通り, 脳に到達していると推測し ている.

\section{4. 鼻腔内投与された分子の作用}

鼻腔内から投与した分子は, 脳機能に大きな影響 を与える。 $\gamma$ (gamma)-aminobutyric acid（GABA） は先に述べたように，水溶性が非常に高く，脳血管 関門を透過し難い薬物である。一方，嗅上皮一嗅球 経路で最初に到達する嗅球は, 嗅覚一次中枢として 機能している．嗅細胞からの匂い情報は僧帽細胞に 伝えられる，僧帽細胞は，梨状皮質，前嗅核や嗅結 節などの嗅皮質にさらに情報を伝えている。 その 際，嗅球に存在する GABA 作動性神経である傍糸 球体細胞や顆粒細胞が，側方抑制の機序により匂い 識別能力を向上させている．また，顆粒細胞にも GABA 受容体が存在し，脳波のオシレーションの 発生に関与している可能性が考えられている. ${ }^{16)}$ そ こで，われわれの研究室の堀内は，マウス鼻腔内に GABA を投与して，嗅覚機能にどのような影響が 生ずるかを調べた。その結果，鼻腔内に投与した GABA は，一般的な匂い応答を抑制した（未発 表)。同時に，椄歯類や有蹄類などで生殖や社会行 動に深く関与しているフェロモンに対する応答も抑 制した。また，6-OHPA を投与して作製したパー キンソン病モデルラットの鼻腔に L-DOPA を投与 すると, 行動が改善する. ${ }^{17)}$ ステロイドホルモンの 
プロゲステロンを鼻腔内投与すると，扁桃体基底外 側部と新線条体のドーパミン濃度が増加する. ${ }^{18)}$ 同 様に，テストステロンは新線条体と側坐核のドーパ ミンとセロトニン濃度を増加させる。鼻腔内に投与 された向神経薬であるコカイン，アンフェタミンや L-DOPA は，新線条体のドーパミン濃度を増加さ せる. ${ }^{19)}$

嗅上皮から脳内へは，われわれにとって有用な物 質が移行するだけではない，例えば，脳炎を引き起 こすウイルスは劦威と言える，われわれの研究室の 笹島は，農薬として広く使われるロテノンを使用し ている農民は，パーキンソン病が通常よりも高い確 率でみられること20) と嗅上皮一嗅球の経路に注目し て実験を行った。 その結果，ロテノンを鼻腔内に投 与すると，嗅球に存在する神経細胞が傷害を受ける ことを見い出した (未発表)。この結果は，噴霧さ れる形で使用される農薬を始めとして，様々な揮発 性の有毒物質が脳内に移行して神経障害を引き起こ す危険性を警鐘する。

さらに大きな分子も嗅上皮から脳内に移行して, 様々な影響をおよぼすことが示されている．中大脳 動脈を閉塞して実験的に脳虚血を生じさせたラット にIGF-I を鼻腔内から投与すると，脳虚血により 障害を受けたいくつかの運動機能が 25 分から 72 分 という比較的短時間で改善するとともに梗塞部位が 減少する. ${ }^{21)}$ 摂食を調節する中枢として，視床下部 が考えられている，視床下部には，血中グルコース 濃度が上昇すると興奮する神経が存在する満腹中枢 と，満腹中枢の神経が興奮することにより抑制され るとともにグルコース濃度の上昇によっても Na-K ポンプの活性化により過分極する摂食中枢が存在す る．満腹中枢を破壊すると動物は肥満を呈し，摂食 中枢を破壊するとやせる。逆に，満腹中枢を電気刺 激すると動物はやせ，摂食中枢を刺激すると肥満を 呈する．満腹中枢にはレプチンに対する受容体を有 する神経が存在している。われわれは，レプチンを 鼻腔内に投与して摂食と体重に対する効果を調べ た。その結果，マウスの摂食は減少した．体重も有 意な差はみられなかったが減少した。また，レプチ ンは満腹中枢の神経細胞に神経興奮の指標となる c-Fos タンパク質の発現を引き起こした。 これらの 結果は，鼻腔内に投与したレプチンが，満腹中枢に 作用して摂食を抑制した可能性を示唆する（菅原
ら，未発表)。同様に，レプチンをラット鼻腔内に 4 週間投与しても，体重増加がコントロールと比べ て減少する. ${ }^{22)}$ このとき，摂食量と飲水量も低下す る。また，傍室核と扁桃体中央核では，コルチコト ロピン放出因子 mRNA が増え，弓状核ではニュー ロトロピンYの mRNA が増える。 また，ヒトがん 細胞を脳内に移植したラットは，平均 35 日程度し か生きられない。このラットにテロメラーゼ阻害効 果を有するヌクレオチド（GRN163）を毎日 12 日 間にわたって鼻腔内に投与すると，75.5 日間まで 生存するような延命効果を示す。 ${ }^{23)}$

抗 NGF 抗体を産生するように遺伝子改変された マウス（AD11）では，基底前脳でのコリン作動性 神経の減少，嗅内皮質でのタウタンパク質の異常な リン酸化及び海馬でのアミロイド $\beta$ タンパク質の クラスター形成がみられる. ${ }^{24)}$ 鼻腔よりヒト NGF を投与すると，これらの障害が回復する，AD11 マ ウスは，行動学的にもアルツハイマー病モデルとし て視覚認知記憶や空間記憶の低下が認められる。マ ウス NGF を鼻腔内投与すると，これらの記憶障害 が回復する. ${ }^{25)}$ また，オープンフィールドテストと 痛覚過敏テストを行いマウスのストレスを調べる と，テストの 1 時間前に抗グルタミン酸抗体を鼻腔 内投与するとストレス反応が抑制される. ${ }^{26)}$ 逆に, 抗 GABA 抗体を鼻腔内に投与すると，ストレス反 応が増強した。

また，鼻腔内投与は，病態の解明を目的とする研 究にも有効である. アルツハイマー病の原因の 1 つ として考えられるアミロイド $\beta$ タンパク質もラッ 卜の鼻腔内に投与すると，2 時間あまりで左右の嗅 球に移行する. ${ }^{27)}$ ウォーターメイズを用いて記憶能 力を調べると，鼻腔から投与されたアミロイド $\beta$ タンパク質は長期の空間記憶を障害する.アルツハ イマー病の 1 つの症状として嗅覚障害が認められて いる，われわれは，マウスの鼻腔にヒトアミロイド $\beta$ タンパク質を投与して，嗅覚応答に対する影響を 調べた。先に述べたように，ヒトを除く多くの哺乳 動物では，フェロモンが第 2 の匂い情報として重要 な役割を演じている。フフロモン，ヒトでは退化 した鋤鼻器と呼ばれる特殊な器官で受容されてい る、鋤鼻器は筒状の形態をしており，フェロモンが 環境に存在するときのみにフェロモンを含有する粘 液を取り込む鋤鼻ポンプという機能が備わつてい 
る。すなわち，アミロイド $\beta$ タンパク質を含む溶 液で処理したときには，フェロモンが含まれていな いので, 鋤鼻器に存在する感覚細胞には直接毒性を 発揮しない。そこで，一般的な揮発する性質を有す る匂い物質とフェロモンを含むマウスの尿を刺激物 質として用いて，アミロイド $\beta$ タンパク質の嗅覚 機能への影響を調べた。アミロイド $\beta$ タンパク質 を鼻腔内に投与すると, 投与しないマウスと比べて 一般的な匂い情報が送られる嗅球での神経活動の低 下がみられた。ささに，鋤鼻器からの神経情報が送 られる副嗅球でも神経活動の低下がみられた。この 結果は，アミロイド $\beta$ タンパク質は嗅球及び副嗅 球の神経細胞に作用して匂い認知脳の低下を引き起 こす可能性を示唆した.

鼻腔内から投与された薬物の効果は，霊長類でも 報告されている．マカクザルを 30 から 36 時間断眠 させると，短期記憶タスクのパフォーマンスが低下 する。それとともに，タスク遂行時に前頭前皮質の 背外側部，線条体及び視床のグルコース代謝率が低 下し，内側側頭葉の代謝率が充進する。オレキシ ン-A を静脈内投与すると, タスクのパフォーマン スの低下が少し改善されるとともにタスク遂行中の グルコース代謝率の変化が緩和される。一方，オレ キシンを鼻腔内に投与すると, 静脈内投与と比べて タスクのパフォーマンスの低下が大きく改善され, 前頭前皮質の背外側部，線条体及び視床のグルコー ス代謝率は顕著に増加する. ${ }^{28)}$

ヒトでも鼻腔内投与による薬物効果が報告されて いる. メラニン細胞刺激ホルモン（melanocytestimulating hormone; MSH), バソプレッシンやイ ンスリンをヒトの鼻腔に投与すると 30 分以内に脳 脊髄液中でこれらのホルモンの濃度の増加がみられ る. ${ }^{29)} 6$ 週間にわたつて毎日 MSH を鼻腔内投与す ると, 体重, 体脂肪, 及び血漿中のレプチンとイン スリンの濃度の低下が認められた. ${ }^{30)}$ 脱力発作を伴 うナルコレプシーの患者では, 脳脊髄液中のオレキ シン濃度は極度に低下するとともに嗅覚障害がみら れる。一方，オレキシン神経は嗅上皮から嗅内皮質 までの嗅覚経路を支配している，オレキシンの鼻腔 内投与は，嗅覚機能を改善する. ${ }^{31}$

鼻腔内に投与されたインスリンは，比較的短い時 間で脳機能を変化させる，警戒課題を行っていると きの聴性誘発脳波の潜時と大きさは，インスリンの
Table 1. List of Molecules, Virus and Cells Delivered from the Olfactory Epithelium to the Brain

\begin{tabular}{|c|c|c|}
\hline Animals & Molecules (low MW) & MW \\
\hline \multirow[t]{16}{*}{ Rat } & amphetamine $^{19)}$ & 135 \\
\hline & dopamine ${ }^{6,7,36)}$ & 154 \\
\hline & L-DOPA $^{17,19)}$ & 197 \\
\hline & meptazinol $^{9)}$ & 233 \\
\hline & lidocaine ${ }^{10)}$ & 234 \\
\hline & estradiol ${ }^{37)}$ & 272 \\
\hline & morphine $^{38)}$ & 285 \\
\hline & testosterone ${ }^{39)}$ & 288 \\
\hline & cocaine $^{19)}$ & 303 \\
\hline & aflatoxin $\mathrm{B}^{40,41)}$ & 312 \\
\hline & progesterone $^{18)}$ & 314 \\
\hline & pregnenolone ${ }^{42)}$ & 316 \\
\hline & GW468816 ${ }^{10)}$ & 380 \\
\hline & GR13895010) & 405 \\
\hline & GV196771 10) & 412 \\
\hline & GR138950 ${ }^{8)}$ & 493 \\
\hline \multirow[t]{3}{*}{ Mouse } & GABA & 103 \\
\hline & dopamine $^{8)}$ & 154 \\
\hline & rotenone & 394 \\
\hline \multirow[t]{2}{*}{ Gilt } & androstenol ${ }^{43)}$ & 274 \\
\hline & Molecules (high MW) & \\
\hline \multirow[t]{5}{*}{ Rat } & orexin- $\mathrm{A}^{44)}$ & 3561 \\
\hline & human $\beta$-amyloid 27 ) & 4615 \\
\hline & IGF-I $^{21,45)}$ & 7649 \\
\hline & leptin 22,46$)$ & 16000 \\
\hline & interferon- $\beta^{47)}$ & 22500 \\
\hline \multirow[t]{5}{*}{ Mouse } & human $\beta$-amyloid & 4615 \\
\hline & $\mathrm{NGF}^{48)}$ & 13000 \\
\hline & leptin & 16000 \\
\hline & anti-Glu antibody ${ }^{26)}$ & \\
\hline & anti-GABA antibody ${ }^{26)}$ & \\
\hline \multirow[t]{2}{*}{ Monkey } & orexin- $\mathrm{A}^{28)}$ & 3561 \\
\hline & interferon- $\beta^{49)}$ & 22500 \\
\hline \multirow[t]{5}{*}{ Human } & orexin- $\mathrm{A}^{31)}$ & 3561 \\
\hline & vasopressin $^{29)}$ & 1056 \\
\hline & insulin ${ }^{33-35)}$ & 5808 \\
\hline & melanocortin $(\mathrm{MSH})^{30)}$ & \\
\hline & Nucleotides & \\
\hline \multirow[t]{2}{*}{ Rat } & siRNA $^{50)}$ & \\
\hline & GRN163 23) & \\
\hline \multirow[t]{2}{*}{ Mouse } & plasmid DNA $^{51)}$ & \\
\hline & Virus & \\
\hline Rat & Borna virus ${ }^{12)}$ & \\
\hline \multirow[t]{2}{*}{ Mouse } & mouse hepatic virus ${ }^{14)}$ & \\
\hline & Cells & \\
\hline \multirow[t]{2}{*}{ Rat } & human glioma ${ }^{15)}$ & \\
\hline & rat mesenchymal stem cells ${ }^{15)}$ & \\
\hline
\end{tabular}

投与 60 分後には変化する. ${ }^{32)}$ 健常人に 8 週間イン スリンを鼻腔内投与すると, 血中のグルコース濃度 
と血漿中のインスリン濃度は変化しないが，覚えた 単語を 1 週間後に思い出す陳述記憶が向上するとと もに，怒りの感情が低下し，自分に対する自信が高 まるなどムードの向上がみられる. ${ }^{33)}$ さらに，1 日 2 回インスリンを鼻腔内投与して，4 カ月後に調べ ると, 健忘性軽度認知障害か改善する. ${ }^{34)}$ また, 1 日 4 回鼻腔内投与すると，男性では，6 週目から体 重の減少がみられる。インスリンの投与を停止する と，4.5 カ月経つと体重の回復が認められる. ${ }^{35)}$ 同 様に，8 週間インスリンの投与を受けた男性では， 体脂肪， ウエストサイズ及びレプチンの減少がみら れる。一方，女性は，細胞外液が増えるためか，个 ンスリン投与 1 週間後から体重の増加がみられた. インスリンの鼻腔内投与は, 脳機能にも影響を与え る.

\section{5. おわりに}

Table 1 では，鼻腔内投与により脳に移行する, あるいは，移行したために神経機能に影響を与えた 可能性が報告されている分子，ウイルス及び細胞を 示している. このように，ラットやマウスでは，多 くの薬物や毒物が鼻腔内投与により，脳血管関門を 経由せずに中枢へ移行し，神経細胞に作用をおよぼ す可能性が示されている，ヒトの場合は，脳の容量 と比べて嗅球の容量は圧倒的に小さい.このため, 十分な薬物が脳に運ばれるか否かについては疑問も 残る。しかしながら，鼻腔内投与した分子が，脳機 能に影響を与えている例も報告されていることか ら，非侵襲的な投与経路として検討する価値が十分 にあると思われる。

\section{REFERENCES}

1) Pardridge W. M., J. Neurochem., 70, 17811792 (1998).

2) Graziadei P. P., Graziadei G. A., J. Neurocytol., 8, 1-18 (1979).

3) Field P., Li Y., Raisman G., J. Neurocytol., 32, 317-324 (2003).

4) Smithson L. J., Kawaja M. D., J. Neurosci. Res., 88, 858-865 (2010).

5) Franssen E. H., De Bree F. M., Verhaagen J., Brain Res. Rev., 56, 236-258 (2007).

6) Dahlin M., Jansson B., Bjork E., Eur. J. Pharm. Sci., 14, 75-80 (2001).

7) Souza Silva M. A., Topic B., Huston J. P.,
Mattern C., Synapse, 62, 176-184 (2008).

8) Dahlin M., Bergman U., Jansson B., Bjork E., Brittebo E., Pharm. Res., 17, 737-742 (2000).

9) Shi Z., Zhang Q., Jiang X., Life Sci., 77, 2574 -2583 (2005).

10) Charlton S. T., Whetstone J., Fayinka S. T., Read K. D., Illum L., Davis S. S., Pharm. Res., 25, 1531-1543 (2008).

11) Johnson N. J., Hanson L. R., Frey W. H., Mol. Pharm., 7, 884-893 (2010).

12) Shankar V., Kao M., Hamir A. N., Sheng H., Koprowski H., Dietzschold B., J. Virol., 66, 992-998 (1992).

13) Carbone K. M., Duchala C. S., Griffin J. W., Kincaid A. L., Narayan O., J. Virol., 61, 3431 -3440 (1987).

14) Perlman S., Evans G., Afifi A., J. Exp. Med., 172, 1127-1132 (1990).

15) Danielyan L., Schafer R., Ameln-Mayerhofer A., Buadze M., Geisler J., Klopfer T., Burkhardt U., Proksch B., Verleysdonk S., Ayturan M., Buniatian G. H., Gleiter C. H., Frey W. H., Eur. J. Cell Biol., 88, 315-324 (2009) .

16) Nusser Z., Kay L. M., Laurent G., Homanics G. E., Mody I., J. Neurophysiol., 86, 28232833 (2001).

17) Chao O. Y., Mattern C., Silva A. M., Wessler J., Ruocco L. A., Nikolaus S., Huston J. P., Pum M. E., Brain Res. Bull., 87, 340-345 (2012).

18) Souza Silva M. A., Topic B., Huston J. P., Mattern C., Neuroscience, 157, 196-203 (2008).

19) Souza Silva M. A., Mattern C., Hacker R., Nogueira P. J., Huston J. P., Schwarting R. K., J. Neurochem., 68, 233-239 (1997).

20) Carstens E., Kuenzler N., Handwerker H. O., J. Neurophysiol., 80, 465-492 (1998).

21) Liu X. F., Fawcett J. R., Thorne R. G., DeFor T. A., Frey W. H., J. Neurol. Sci., 187, 91-97 (2001).

22) Schulz C., Paulus K., Lehnert H., Endocrinology, 145, 2696-2701 (2004).

23) Hashizume R., Ozawa T., Gryaznov S. M., Bollen A. W., Lamborn K. R., Frey W. H., Deen D. F., Neuro Oncol., 10, 112-120 (2008).

24) Capsoni S., Giannotta S., Cattaneo A., Proc. 
Natl. Acad. Sci. USA, 99, 12432-12437 (2002).

25) De Rosa R., Garcia A. A., Braschi C., Capsoni S., Maffei L., Berardi N., Cattaneo A., Proc. Natl. Acad. Sci. USA, 102, 3811-3816 (2005).

26) Yevseyev V. A., Zaharova I. A., Vetrile L. A., Bull. Exp. Biol. Med., 148, 12-16 (2009) .

27) Sipos E., Kurunczi A., Feher A., Penke Z., Fulop L., Kasza A., Horvath J., Horvat S., Veszelka S., Balogh G., Kurti L., Eros I., Szabo-Revesz P., Parducz A., Penke B., Deli M. A., Cell. Mol. Neurobiol., 30, 405-413 (2010) .

28) Deadwyler S. A., Porrino L., Siegel J. M., Hampson R. E., J. Neurosci., 27, 1423914247 (2007)

29) Born J., Lange T., Kern W., McGregor G. P., Bickel U., Fehm H. L., Nat. Neurosci., 5, 514 -516 (2002).

30) Fehm H. L., Smolnik R., Kern W., McGregor G. P., Bickel U., Born J., J. Clin. Endocrinol. Metab., 86, 1144-1148 (2001).

31) Baier P. C., Weinhold S. L., Huth V., Gottwald B., Ferstl R., Hinze-Selch D., Brain, 131, 2734-2741 (2008).

32) Kern W., Born J., Schreiber H., Fehm H. L., Diabetes, 48, 557-563 (1999).

33) Benedict C., Hallschmid M., Hatke A., Schultes B., Fehm H. L., Born J., Kern W., Psychoneuroendocrinology, 29, 1326-1334 (2004).

34) Craft S., Baker L. D., Montine T. J., Minoshima S., Watson G. S., Claxton A., Arbuckle M., Callaghan M., Tsai E., Plymate S. R., Green P. S., Leverenz J., Cross D., Gerton B., Arch. Neurol., 69, 29-38 (2012).

35) Hallschmid M., Benedict C., Schultes B., Fehm H. L., Born J., Kern W., Diabetes, 53, 3024-3029 (2004).

36) Pum M. E., Schable S., Harooni H. E., Topic B., Souza Silva M. A., Li J. S., Huston J. P., Mattern C., Neuroscience, 162, 174-183 (2009) .
37) van den Berg M. P., Verhoef J. C., Romeijn S. G., Merkus F. W., Eur. J. Pharm. Biopharm., 58, 131-135 (2004).

38) Westin U., Piras E., Jansson B., Bergstrom U., Dahlin M., Brittebo E., Bjork E., Eur. J. Pharm. Sci., 24, 565-573 (2005).

39) Souza Silva M. A., Mattern C., Topic B., Buddenberg T. E., Huston J. P., Eur. Neuropsychopharmacol., 19, 53-63 (2009).

40) Souza Silva M. A., Topic B., Huston J. P., Mattern C., Neuroscience, 157, 196-203 (2008) .

41) Fei H., Okano H. J., Li C., Lee G. H., Zhao C., Darnell R., Friedman J. M., Proc. Natl. Acad. Sci. USA, 94, 7001-7005 (1997).

42) Ducharme N., Banks W. A., Morley J. E., Robinson S. M., Niehoff M. L., Mattern C., Farr S. A., Eur. J. Pharmacol., 641, 128-134 (2010).

43) Krzymowski T., Grzegorzewski W., Stefanczyk-Krzymowska S., Skipor J., Wasowska B., Theriogenology, 52, 1225-1240 (1999).

44) Dhuria S. V., Hanson L. R., Frey W. H., J. Pharm. Sci., 98, 2501-2515 (2009).

45) Thorne R. G., Pronk G. J., Padmanabhan V., Frey W. H., Neuroscience, 127, 481-496 (2004).

46) Fliedner S., Schulz C., Lehnert H., Endocrinology, 147, 2088-2094 (2006).

47) Ross T. M., Martinez P. M., Renner J. C., Thorne R. G., Hanson L. R., Frey W. H., J. Neuroimmunol., 151, 66-77 (2004).

48) Capsoni S., Giannotta S., Cattaneo A., Proc. Natl. Acad. Sci. USA, 99, 12432-12437 (2002).

49) Thorne R. G., Hanson L. R., Ross T. M., Tung D., Frey W. H., Neuroscience, 152, 785797 (2008).

50) Renner D. B., Frey W. H., Hanson L. R., Neurosci. Lett., 513, 193-197 (2012).

51) Han I. K., Kim M. Y., Byun H. M., Hwang T. S., Kim J. M., Hwang K. W., Park T. G., Jung W. W., Chun T., Jeong G. J., Oh Y. K., J. Mol. Med. (Berl), 85, 75-83 (2007). 